\title{
Non-coincident inter-instrument comparisons of ozone measurements using quasi-conservative coordinates
}

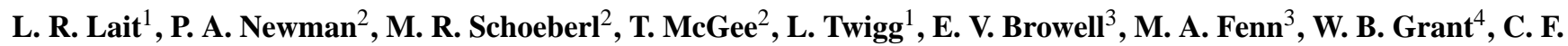 \\ Butler $^{3}$, R. Bevilacqua ${ }^{5}$, J. Davies ${ }^{6}$, H. DeBacker ${ }^{7}$, S. B. Andersen ${ }^{7}$, E. Kyrö ${ }^{8}$, R. Kivi ${ }^{8}$, P. von der Gathen ${ }^{9}$, \\ H. Claude ${ }^{10}$, A. Benesova ${ }^{11}$, P. Skrivankova ${ }^{11}$, V. Dorokhov ${ }^{12}$, I. Zaitcev ${ }^{12}$, G. Braathen ${ }^{13}$, M. Gil ${ }^{14}$, Z. Litynska ${ }^{15}$, \\ D. Moore $^{16}$, and M. Gerding ${ }^{17}$
}

${ }^{1}$ Science Systems and Applications, Inc., Lanham, Maryland, USA

${ }^{2}$ NASA Goddard Space Flight Center, Greenbelt, Maryland, USA

${ }^{3}$ NASA Langley Research Center, Langley, Virginia, USA

${ }^{4}$ SUNARC, San Francisco, California, USA

${ }^{5}$ U. S. Naval Research Laboratory

${ }^{6}$ Meteorological Service of Canada, Ontario, Canada

${ }^{7}$ Danish Meteorological Institute, Copenhagen, Denmark

${ }^{8}$ Finnish Meteorological Institute, Sodankylä, Finland

${ }^{9}$ Alfred Wegener Institute, Potsdam, Germany

${ }^{10}$ Deutscher Wetterdienst Meteorologisches Observatorium, Hohenpeissenberg, Germany

${ }^{11}$ Czech Hydrometeorological Institute, Prague, Czech Republic

${ }^{12}$ Central Aerological Observatory, Dolgoprudny, Russia

${ }^{13}$ Norsk Institutt for Luftforskning, Kjeller, Norway

${ }^{14}$ Instituto Nacional de Técnica Aeroespacial, Madrid, Spain

${ }^{15}$ Institute of Meteorology and Water Management, Legionowo, Poland

${ }^{16}$ U. K. Meteorological Office, Wokingham, Berks, United Kingdom

${ }^{17}$ Leibniz-Institute of Atmospheric Physics, Kühlungsborn, Germany

Received: 28 May 2004 - Published in Atmos. Chem. Phys. Discuss.: 5 August 2004

Revised: 8 November 2004 - Accepted: 19 November 2004 - Published: 30 November 2004

\begin{abstract}
Ozone measurements from ozonesondes, AROTAL, DIAL, and POAM III instruments during the SOLVE2/VINTERSOL period are composited in a time-varying, flow-following quasi-conservative (PV- $\theta$ ) coordinate space; the resulting composites from each instrument are mapped onto the other instruments' locations and times. The mapped data are then used to intercompare data from the different instruments. Overall, the four ozone data sets are found to be in good agreement. AROTAL shows somewhat lower values below $16 \mathrm{~km}$, and DIAL has a positive bias at the upper limits of its altitude range. These intercomparisons are consistent with those obtained from more conventional near-coincident profiles, where available. Although the PV- $\theta$ mapping technique entails larger uncertainties of individual profile differences compared to direct near-coincident comparisons, the ability to include much larger numbers of comparisons can make this technique advantageous.
\end{abstract}

Correspondence to: L. R. Lait

(lait@code916.gsfc.nasa.gov)

\section{Introduction}

The Kiruna deployments of the SOLVE-2 and VINTERSOL field experiments took place in January and February 2003. During this period, a number of different instruments measured stratospheric ozone. On board the NASA DC8 aircraft were the Airborne Raman Ozone, Temperature, and Aerosol Lidar (AROTAL) and the Differential Absorption Lidar (DIAL), as well as in situ instruments such as FAST response OZone instrument (FASTOZ) and the Gas and Aerosol Measurement Sensor/Langley Airborne A-Band Spectrometer (GAMS/LAABS). Other instruments, such as the balloon-borne MkIV interferometer, flew on other platforms or took ground-based measurements. A number of sites launched ozonesondes in coordination with the campaigns. In addition, data from the Polar Ozone and Aerosol Measurement III (POAM III) solar occultation instrument on the SPOT-4 spacecraft were made available to the mission teams.

(C) 2004 Author(s). This work is licensed under a Creative Commons License. 
The usual approach to instrument intercomparisons is to select measurements which were taken at nearly the same time and place. Flying on board the NASA DC- 8 together, the AROTAL and DIAL instruments were coincident, and the DC-8 flew over Ny Ålesund in coordination with a number of the sonde launches there. But because many of the instruments operated on different platforms at different times and locations, opportunities for measurement intercomparison were less than plentiful for most instruments. Aside from the AROTAL/DIAL data, the small number of nearcoincident measurement sets make a statistical evaluation of inter-instrument differences problematic. Other approaches exist which do not depend on coincidence of the measurements being compared. The trajectory-mapping approach of Morris et al. (2000), the trajectory-hunting method of Danilin et al. (2003), and the MATCH technique of Rex et al. (1999) are examples.

In this work, a quasi-conservative coordinate method is employed. Described in Schoeberl and Lait (1991), this technique depends upon the premise that a reasonably long-lived trace gas should be well-mixed along contours of potential vorticity $(\mathrm{PV})$ on a surface of constant potential temperature $(\theta)$ (Leovy et al., 1985). By using PV and $\theta$ as coordinates, averaging mixing ratios near a set of points in that coordinate space should yield an accurate picture of a time-invariant trace gas distribution in PV- $\theta$ space, in the absence of diabatic effects and chemical changes. In the lower stratosphere at middle to higher latitudes, these latter effects often may safely be ignored for short time periods of approximately 10 days or less. For longer periods, they must be taken into account somehow.

PV- $\theta$ analysis was used in Schoeberl et al. (1989), Lait et al. (1990), and Randall et al. (2002) to map measurements onto a three-dimensional field, and in Kyrö et al. (2000) and Lait et al. (2002) to determine stratospheric ozone loss in the Arctic. Lary et al. (1995) used a similar method to initialize model simulations. The quasi-conservative coordinate method can be also useful in inter-instrument comparisons, as seen in Redaelli et al. (1994) and Manney et al. (2001).

In this work, we intercompare ozone measurements from several instruments during the SOLVE-2/VINTERSOL period. Section 2 describes each of these data sets briefly; then the analysis technique is described in Sect. 3. Results follow in Sect. 4.

\section{Data}

The SOLVE-2/VINTERSOL joint field experiment took place in January through early February 2003. We used data from four instruments: AROTAL, DIAL, POAM III, and the ozonesondes. Measurements were used from January 1 through February 10.

The NASA Goddard Space Flight Center's AROTAL instrument is a lidar that uses Rayleigh scattering from xenon chloride eximer and Nd:YAG lasers transmitting at 308 and $355 \mathrm{~nm}$ to measure ozone, temperature, and aerosols. A more complete discussion of the instrument may be found in McGee et al. (2001) and Burris et al. (2002). For the SOLVE-2/VINTERSOL mission archive, AROTAL reports profiles every $22 \mathrm{~s}$, averaged over $1.2 \mathrm{~min}$. The altitude of the profiles depends on the altitude of the DC- 8 aircraft, but over the middle of the flight the data tend to range from approximately $14 \mathrm{~km}$ to $35 \mathrm{~km}$. Vertical resolution of the reported data is approximately $150 \mathrm{~m}$. Data were collected for 12 flights of the DC-8. To avoid problems with sunlight increasing noise in the measurements, only profiles taken where the local solar zenith angle is greater than $95^{\circ}$ were used.

A second lidar, the NASA Langley Research Center's DIAL instrument, also flew on the DC-8. This instrument uses two Nd:YAG lasers transmitting at multiple frequencies to observe ozone below and above the aircraft. The DIAL data in the mission archive consist of profiles spaced about a minute apart. As with AROTAL, the altitudes covered change with the altitude of the aircraft, but typical coverage is from a few kilometers above the surface to around $25 \mathrm{~km}$, with a small altitude gap near the aircraft itself. Vertical resolution reported is approximately $75 \mathrm{~m}$. Data were collected for 14 flights (including two pre-mission test flights before the deployment to Kiruna). Details of this instrument may be found in Browell et al. (2003), Browell et al. (1998), and Richter et al. (1997).

A total of 214 balloon-launched sonde profiles from 21 ground stations were used in this analysis. These included special sondes launched for VINTERSOL, as well as those launched by the Meteorological Service of Canada, the World Meteorological Organization network, Japan, and Russia. Data were used from the stations shown in Table 1. (Beginning and ending dates shown are confined to the time period examined here.) Altitude ranges vary greatly, but the sondes got as high as $29 \mathrm{~km}$. Reported vertical resolution also varies, from about $10 \mathrm{~m}$ to around $60 \mathrm{~m}$.

The POAM III solar occultation instrument is described in Lucke et al. (1999). It is a nine-channel photometer that uses solar occultation to measure atmospheric extinction in bands from 0.354 to $1.018 \mu \mathrm{m}$ to retrieve temperature and multiple species, including ozone. Fourteen profiles are taken in the Northern Hemisphere each day (as well as fourteen in the Southern Hemisphere), spaced around a latitude circle that moves slowly in time. Vertical resolution is approximately $1 \mathrm{~km}$ (Lumpe et al., 2003).

To apply the quasi-conservative coordinate analysis, values of potential vorticity and potential temperature must be obtained at each measurement location and time. For this work, these are obtained by interpolating three-dimensional gridded analyses from the Data Assimilation Office (now the Global Modeling and Assimilation Office) of NASA's Goddard Space Flight Center. These analyses were chosen because of their relatively fine horizontal and temporal resolution, as well as their altitude range. The analyses used 
Table 1. Ozonesonde stations

\begin{tabular}{lrrccc}
\hline Station & Longitude & Latitude & No.Profiles & Beg. Date & End. Date \\
\hline Alert & -62.33 & 82.50 & 13 & Jan. 3 & Feb. 10 \\
Churchill & -94.07 & 58.74 & 8 & Jan. 1 & Feb. 5 \\
Eureka & -85.94 & 79.99 & 11 & Jan. 3 & Feb. 10 \\
Goosebay & -60.36 & 53.31 & 7 & Jan. 8 & Feb. 5 \\
Resolute & -94.97 & 74.71 & 7 & Jan. 2 & Feb. 10 \\
Stonyplain & -114.11 & 53.55 & 5 & Jan. 1 & Jan. 29 \\
Hohenpeissenberg & 11.00 & 47.80 & 17 & Jan. 1 & Feb. 10 \\
Jokioinen & 23.50 & 60.80 & 9 & Jan. 3 & Feb. 8 \\
Sodankyla & 26.65 & 67.39 & 25 & Jan. 1 & Feb. 9 \\
Keflavik & -22.60 & 63.97 & 9 & Jan. 3 & Feb. 7 \\
Kuehlungsborn & 11.77 & 54.12 & 2 & Feb. 3 & Feb. 4 \\
Legionowo & 20.97 & 52.40 & 9 & Jan. 8 & Feb. 5 \\
Lerwick & -1.18 & 60.13 & 3 & Jan. 5 & Jan. 11 \\
Ny Ålesund & 11.95 & 78.93 & 19 & Jan. 6 & Feb. 10 \\
Orland & 9.24 & 63.42 & 6 & Jan. 7 & Feb. 5 \\
Prague & 14.45 & 50.02 & 16 & Jan. 3 & Feb. 10 \\
Scoresbysund & -22.00 & 70.50 & 8 & Jan. 1 & Feb. 7 \\
Thule & -68.74 & 76.53 & 5 & Jan. 14 & Jan. 31 \\
Uccle & 4.35 & 50.8 & 19 & Jan. 3 & Feb. 10 \\
Salekhard & 66.70 & 66.70 & 10 & Jan. 4 & Feb. 6 \\
Yakutsk & 129.63 & 62.03 & 6 & Jan. 8 & Feb. 10 \\
\hline
\end{tabular}

were chosen from the "final look" product generated from the GEOS-4 system. GEOS-4 was the successor to the GEOS-1 system documented by Pfaendtner et al. (1995). These data grids extend from 1000 to $0.2 \mathrm{hPa}$, have a horizontal resolution of $1.25^{\circ}$ longitude by $1.0^{\circ}$ latitude, and are produced four times daily.

\section{Analysis}

In order to derive meaningful statistics for both coincident and non-coincident comparisons, it was necessary to obtain uncertainties associated with the ozone measurements. Such uncertainties are derived from variations of ozone values at a point in PV- $\theta$ space. These variations include not only the instruments' random error, but the small-scale geophysical variability that is not resolved by the gridded meteorological analyses. Both sources of variance are needed for this analysis, and an empirical estimation is useful. To estimate the uncertainties for AROTAL and DIAL, a standard variance profile for each instrument was constructed from the smallscale horizontal variations of all the profiles from all flights. For ozonesondes, we used the larger of $5 \%$ of the measured value, or the variance about a linear fit within a $5 \mathrm{~km}$ segment. However, because small-scale geophysical variability is much less of a problem with the POAM III data, the uncertainties used were taken from the data archive.

The measurements, with their uncertainties, locations, and times were collected for each instrument. (For the sondes, the winds were used to estimate the horizontal location of each balloon during its ascent.) Modified potential vorticity (see Lait, 1994) and potential temperature were interpolated from the meteorological analysis onto the measurement locations and times.

To aid in the statistical analysis, measurements going into the analysis need to be independent of each other. Data with high horizontal or vertical resolution, however, are highly autocorrelated and must therefore be thinned out. By computing autocorrelations of the lidar data along the flight, we were able to estimate the minimum horizontal separation to ensure independence of profiles as approximately $400 \mathrm{~km}$ for AROTAL measurements and $375 \mathrm{~km}$ for DIAL. These distances are roughly consistent with those computed by Schoeberl et al. (2002) for the same instruments. Consequently, roughly ten profiles were used from each flight. Because the profile sites for the sondes and POAM III data were widely separated, horizontal separations were not an issue for those instruments. Minimum vertical separations between a profile's measurements were similarly obtained. For AROTAL, the vertical separation was estimated to be $3 \mathrm{~km}$; for DIAL, it was $4 \mathrm{~km}$. For the sondes, it was $3 \mathrm{~km}$, and for POAM data, $4 \mathrm{~km}$.

The analysis itself is similar to that in Lait et al. (2002). A regular grid in a PV- $\theta$ coordinate space was constructed, and $\mathrm{PV}$ and $\theta$ values interpolated from the analyses were used to locate each ozone measurement in the coordinate space. Data from January 1 through February 10 were used; hence, diabatic effects and chemical changes needed to be accounted for. These effects both show up as a change in ozone over 

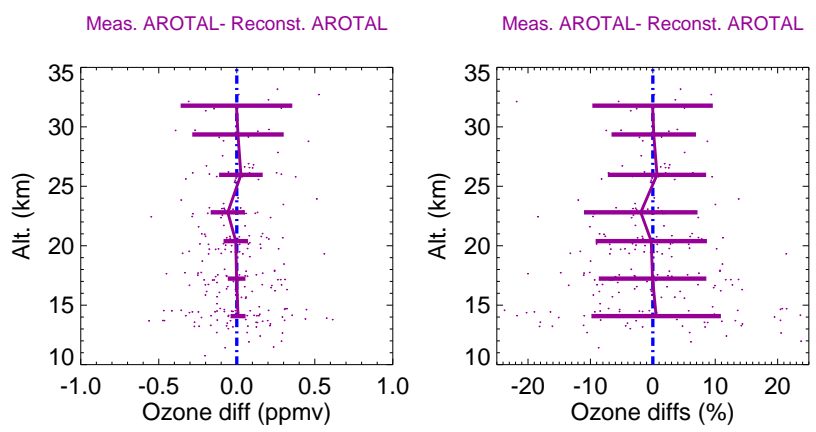

Fig. 1. (left) Self-comparison biases for AROTAL data, expressed as the difference between the original measurements and the measurements reconstructed through PV- $\theta$ mapping. Dots are the individual differences, the thin line is the mean difference profile, and the thick horizontal lines are the $90 \%$ confidence limits of the mean differences. (right) the differences expressed as percentages of the mean profile.
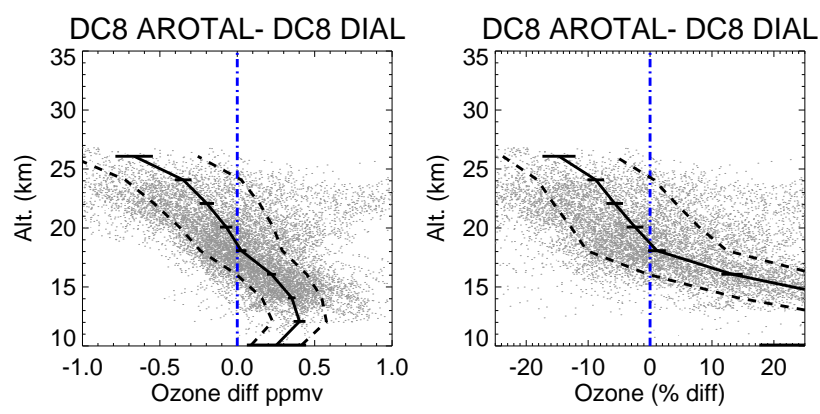

Fig. 2. (Left) Near-coincident differences between AROTAL and DIAL. Gray dots represent individual differences, the solid line shows the mean difference profiles, horizontal lines show the estimated $90 \%$ confidence limits of the mean profile, and the dotted lines show the standard deviation of the differences. (Right) The differences expressed as percentages of the mean profile.

time at a given point in PV- $\theta$ space. To first order, they can be dealt with by applying a weighted linear time fit to the data near a given PV- $\theta$ gridpoint. Each point was weighted inversely to its uncertainty and its distance from the PV- $\theta$ gridpoint being examined.

This procedure yields a set of slopes and intercepts, one for each gridpoint in the PV- $\theta$ coordinate space. From these, we can construct a composite field in PV- $\theta$ space for any moment in time; moreover, given the meteorological analyses we can map this ozone field back into longitude-latitudealtitude space. Note that for instrument comparison purposes here, only the overall evolution of the ozone field is relevant. Whether changes in that field are caused by diabatic effects or by chemical loss/production is of no concern, and so there is no need to try to separate those two effects.

Data from two instruments are compared by constructing a PV- $\theta$ composite field from one instrument and mapping
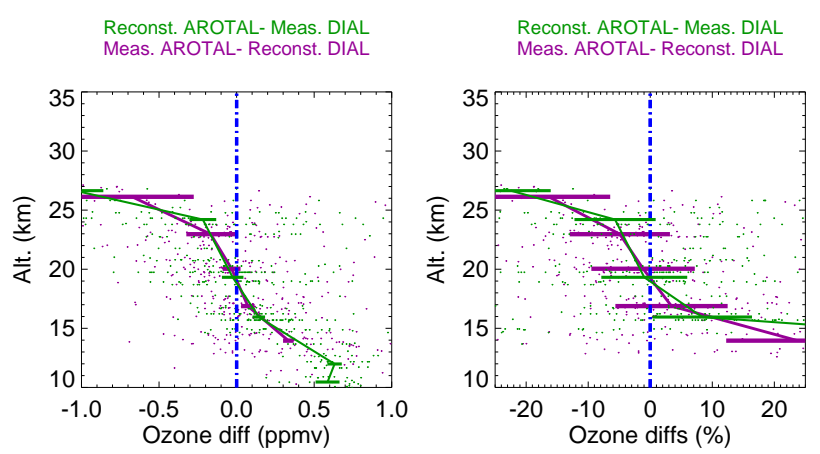

Fig. 3. (Left) Differences between AROTAL and DIAL, using PV- $\theta$ analysis. The mean differences (with their $90 \%$ confidence limits) are shown for the comparisons both using AROTAL data reconstructed onto DIAL measurement locations (thin green line), and DIAL data mapped onto AROTAL locations (thick purple line). (Right) Differences expressed as percentages of the mean profile.

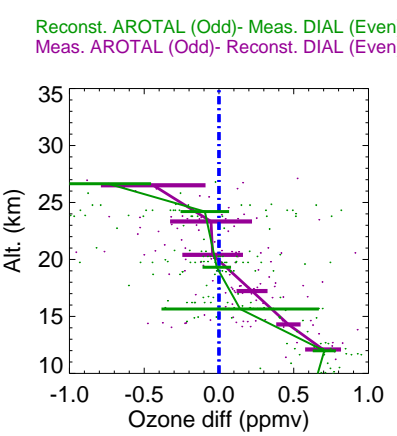

Reconst. AROTAL (Odd)- Meas. DIAL (Even) Meas. AROTAL (Odd)- Reconst. DIAL (Even)

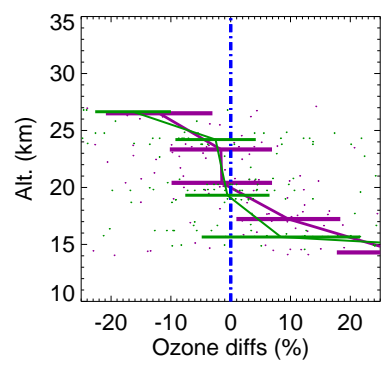

Fig. 4. As in Fig. 3, except that AROTAL data from the oddnumbered DC- 8 flights are compared with DIAL data from the even-numbered flights.

its ozone values onto the locations and times of the second instrument. The differences between the two ozone values and the uncertainties associated with those differences are collected, and mean profiles of the biases are computed for the mission period, taking the uncertainties into account.

\section{Results}

To validate the analysis technique, several tests were applied.

First, each instrument was compared against itself. That is, differences were characterized between the all of the original measurements taken during the time period and those from $\mathrm{PV}-\theta$ mapping of the same instrument's data. This test should reveal any biases or distortions introduced by the analysis technique itself, and it should also reveal the degree to which noise is introduced by errors in the meteorological fields, departures from assumption of being well-mixed, and so on. Figure 1 shows an example of the self-comparison for AROTAL data. The maximum difference, less than 0.1 ppmv near 
Reconst. AROTAL (Even)- Meas. DIAL (Odd) Meas. AROTAL (Even)- Reconst. DIAL (Odd)
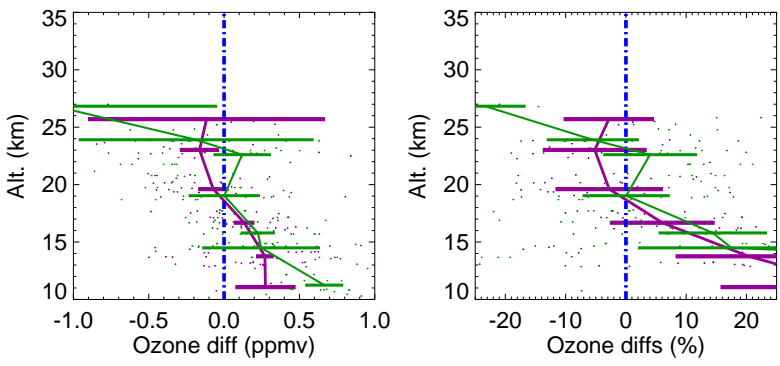

Fig. 5. As in Fig. 3, except that AROTAL data from the evennumbered DC-8 flights are compared with DIAL data from the oddnumbered flights.

$22 \mathrm{~km}$, is not statistically different from zero, and the rest of the profile is very close to zero. The self-comparisons for the other instruments show similar results: very small average differences, with at most minor statistically insignificant fluctuations.

The next test was to compute inter-instrument differences between AROTAL and DIAL using both near-coincident and non-coincident methods. Because both these instruments flew aboard the same aircraft, a large number of nearcoincident profiles could be collected. For the 12 SOLVE-2 flights of the DC-8, the two closest profiles of the two instruments were chosen within each 400-km flight segment; each profile pair in a flight had to be separated from all other profile pairs by at least $400 \mathrm{~km}$. For each profile pair, the DIAL data were then interpolated to the AROTAL altitudes, and the two profiles were differenced. Figure 2 shows the differences and their average profile. Above $20 \mathrm{~km}$, DIAL ozone values start to become systematically higher than AROTAL - up to 0.7 ppmv higher around $25 \mathrm{~km}$. Below $16 \mathrm{~km}$, AROTAL values are higher, up to $0.4 \mathrm{ppmv}$ higher near $12 \mathrm{~km}$.

Comparing the AROTAL and DIAL data using the noncoincident PV- $\theta$ analysis yields similar results (Fig. 3). Note that the measured-reconstructed differences are consistent with the reconstructed-measured differences. Of course, because the data being compared were in fact coincident, this is no more rigorous a test of the noncoincident technique than the self-comparisons. Nevertheless, this comparison is useful for evaluating the success of the next test.

A more demanding test is to compare true non-coincident DIAL and AROTAL data. To accomplish this, AROTAL data from the even-numbered flights were compared with DIAL data from the odd-numbered flights, and vice-versa. The results, shown in Figs. 4 and 5, are consistent with the near-coincident comparisons, albeit with larger uncertainties (since they involved only half the data). Figure 4 matches the full data comparison quite well, while Fig. 5 has greater uncertainties but is still roughly consistent with the others.
Reconst. AROTAL- Meas. Sondes Meas. AROTAL- Reconst. Sondes

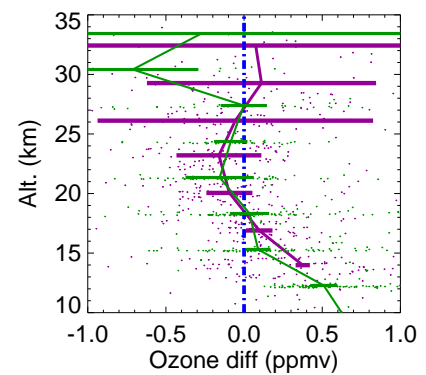

Reconst. AROTAL- Meas. Sondes Meas. AROTAL- Reconst. Sondes

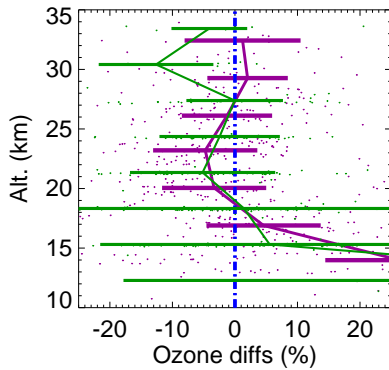

Fig. 6. As in Fig. 3, except that AROTAL data are compared with data from the ozonesondes.
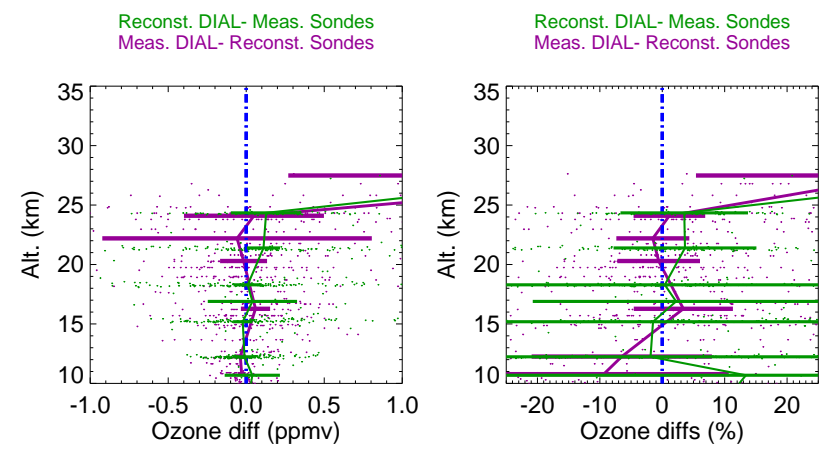

Fig. 7. As in Fig. 3, except that DIAL data are compared with data from the ozonesondes.

Note that the altitude ranges of the two curves in each plot differ. DIAL measures ozone profiles below the aircraft as well as above. However, vertical undulations of isentropic surfaces enable the AROTAL measurements to sample regions of PV- $\theta$ space which can be mapped into lower altitudes than the instrument actually measured.

Having confirmed that each instrument's data compare well with themselves, and that the AROTAL-DIAL noncoincident comparisons are similar to the coincident comparisons, we proceeded to compare the other instruments' data.

Figure 6 shows the differences between AROTAL and the ozonesondes. There appears to be a bias below $15 \mathrm{~km}$, with AROTAL being perhaps 0.3 to 0.4 ppmv higher than the sondes near 12-13 km. Above $25 \mathrm{~km}$, the ozonesondes are fewer in number and their uncertainties are often larger, so that the error bars in the differences are much larger at those altitudes. Nevertheless, there is some suggestion of AROTAL data being systematically lower than the sondes at these altitudes. (Note also the error bars in the percentage plot depend on the variance in the mean profile as well as the mean difference, and the resulting uncertainties are larger at lower altitudes as a result.) 

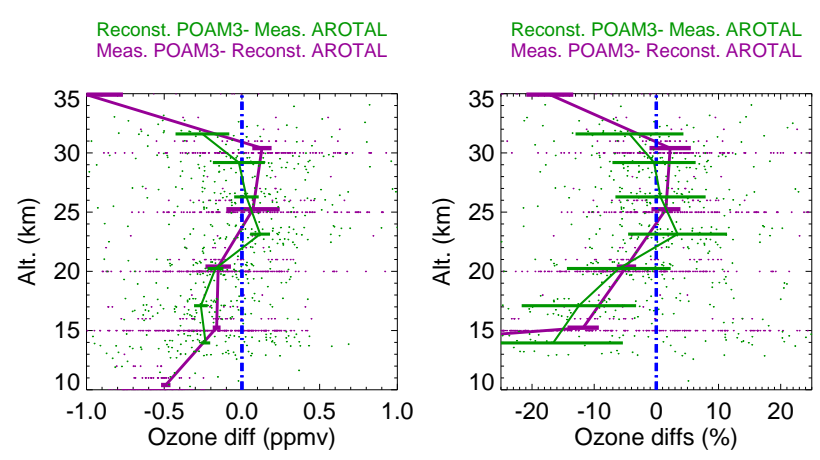

Fig. 8. As in Fig. 3, except that AROTAL data are compared with data from POAM III.
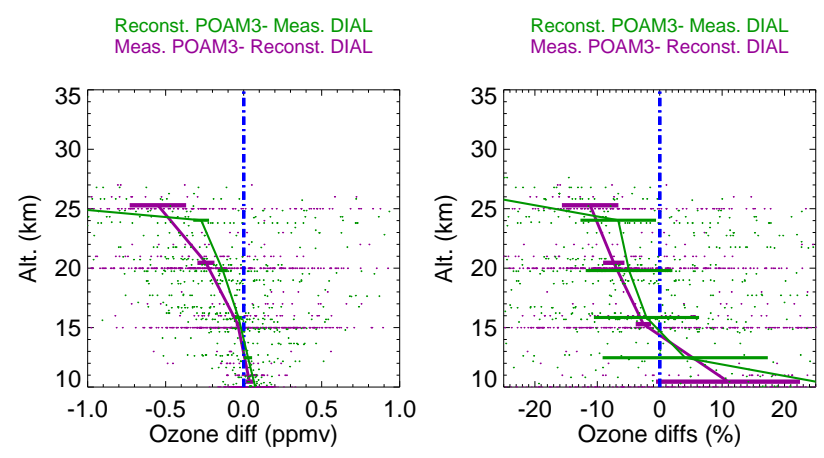

Fig. 9. As in Fig. 3, except that DIAL data are compared with data from POAM III.

Likewise, the differences between DIAL and the sondes is shown in Fig. 7. Here, DIAL matches the sondes well at the lower altitudes, but DIAL is higher at the uppermost reaches of the instrument, above $25 \mathrm{~km}$. This is only one altitude, however, and it is associated with a large uncertainty. But the AROTAL-sonde and DIAL-sonde differences are consistent with the AROTAL-DIAL differences.

Figures 8 and 9 show the POAM-AROTAL and POAMDIAL differences, respectively. The POAM-AROTAL differences are qualitatively similar to biases noted in Lumpe et al. (2003), where coincident comparisons were made between POAM III and AROTEL (an earlier version of AROTAL) and DIAL during the first SOLVE campaign in the winter of 1999-2000. The POAM-DIAL differences at the uppermost DIAL altitudes, however, are of different sign from those in Lumpe et al. (2003).

Figure 10 compares the ozonesonde data with the POAM III profiles. The two data sets agree below $18 \mathrm{~km}$, but a possible small bias appears near $20 \mathrm{~km}$, with the sondes being about 0.2 ppmv higher. At higher altitudes, between 25 and $30 \mathrm{~km}$, there is also a suggestion of a small positive bias of $0.2 \mathrm{ppmv}$, relative to the sondes, but the sonde measurements are fewer and less certain here. Using coincident comparisons, Randall et al. (2002) found no systematic bias
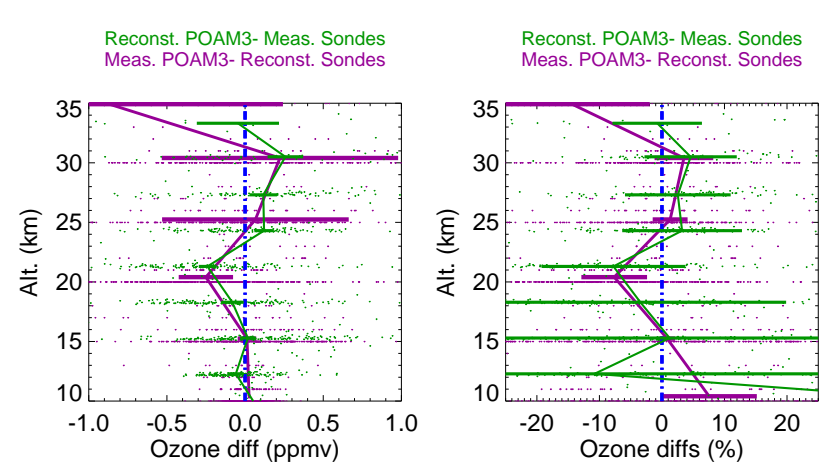

Fig. 10. As in Fig. 3, except that ozonesonde data are compared with data from POAM III.

between sondes and POAM between 13 to $60 \mathrm{~km}$, but they did find evidence for a $0.1 \mathrm{ppmv}$ positive POAM bias between 10 to $12 \mathrm{~km}$,

These intercomparisons were repeated with other meteorological analyses (UARS UKMO Assimilation, NCAR/NCEP Reanalysis, and NCEP Spectral Statistical Interpolation products); the results were similar.

\section{Conclusions}

Ozone measurements taken during the SOLVE2/VINTERSOL field experiment from four instruments (AROTAL, DIAL, POAM III, and sondes) were compared. A quasi-conservative coordinate approach was employed to use non-coincident data for instrument intercomparisons. Several tests of the method were applied. First, each instrument's data were self-compared; the differences were zero, within the uncertainty associated with the technique. Second, the AROTAL and DIAL data were compared, with results similar to those from the straightforward near-coincident comparison. These tests demonstrate that the quasi-conservative technique does not introduce unusual or misleading artifacts into the data. To provide a true non-coincident data comparison, the DIAL data from the odd-numbered DC-8 flights were compared with AROTAL data from the even-numbered flights, and vice versa. These results were consistent with the other DIAL-AROTAL comparisons, although the uncertainties were larger.

Finally, all four data sets were intercompared. By finding commonalities among the intercomparisons, it is possible to determine which instruments exhibit systematic biases at which altitudes. The AROTAL data exhibit a positive bias of 0.3 to $0.7 \mathrm{ppmv}$ at altitudes below $16 \mathrm{~km}$ (roughtly $20 \%$ at those altitudes), when compared to DIAL, the sondes, and POAM. DIAL, however, shows a positive bias of 0.5 to $1.0 \mathrm{ppmv}(15-20 \%)$ at its uppermost altitude range (above $25 \mathrm{~km}$ ), when compared to AROTAL, POAM, and perhaps the sondes. AROTAL and DIAL agree within $0.25 \mathrm{ppmv}$, or better than $10 \%$, from about $17 \mathrm{~km}$ to $22 \mathrm{~km}$, according to 
the coincident comparisons; this is consistent with the noncoincident comparisons.

The ozonesonde and POAM data appear to be of very good quality, on average. The two match each other well, except for a possible small bias in a region near $20 \mathrm{~km}$. DIAL compares very well with the sonde data (better than 5\%) between 13 and $25 \mathrm{~km}$, consistent with the DIAL/POAM comparison. AROTAL, too, compares well ( $6 \%$ or better) with POAM and the sondes above around $20 \mathrm{~km}$, up to $30 \mathrm{~km}$, although the POAM/AROTAL comparisons suggest a high bias for AROTAL at its highest altitudes.

This PV- $\theta$ analysis produces results with substantial uncertainties. The uncertainties associated with the limitedresolution analyzed $\mathrm{PV}$ and $\theta$ meteorological fields, limited sampling over regions of PV- $\theta$ space, potential failures in the assumptions necessary for the method's validity (e.g. homogeneity around a circumpolar PV- $\theta$ tube), and even a breakdown in PV-ozone correlations at high altitudes and low latitudes, can all contribute to the enlarged error bars. Certainly, then, direct comparison of large numbers of near-coincident measurements is preferred where it is possible. Nevertheless, the higher numbers of comparisons which are made possible by relaxing the requirement for near-coincidence, can improve the statistics so that the results are useful despite their uncertainties.

Acknowledgements. We wish to acknowledge the DC-8 pilots and the flight and ground crews who made the aircraft measurements possible under sometimes difficult conditions; the sonde launch personnel; the SOLVE-2 logistics staff and the personnel of the Arena Arctica in Kiruna, Sweden; and SOLVE-2 and VINTERSOL management. This research was supported by the NASA's Atmospheric Chemistry Modeling and Analysis Program and the Upper Atmosphere Research Program and NASA's EOS Interdisciplinary Science Program.

Edited by: K. Carslaw

\section{References}

Browell, E. V., Ismail, S., and Grant, W. B.: Differential Absorption Lidar (DIAL) measurements from air and space, Appl. Phys.-B, 67, 399-410, 1998.

Browell, E. V., Fenn, M. A., Butler, C. F., Grant, W. B., Brackett, V. G., Hair, J. W., Avery, M. A., Newell, R. E., Hu, Y., Fuelberg, H. E., Jacob, D. J., Anderson, B. E., Atlas, E. L., Blake, D. R., Brune, W. H., Dibb, J. E., Fried, A., Heikes, B. G., Sachse, G. W., Sandholm, S. T., Singh, H. B., Talbot, R. W., Vay, S. A., Weber, R. J., and Bartlett, K. B.: Large-scale ozone and aerosol distributions, air mass characteristics, and ozone fluxes over the western Pacific Ocean in late winter/early spring, J. Geophys. Res., 108, doi:10.1029/2002JD003290, 2003.

Burris, J., McGee, T., Hoegy, W., Lait, L., Twigg, L., Sumnicht, G., Heaps, W., Hostetler, C., Bui, T. .P., Neuber, R., and McDermid, I. S.: Validation of temperature measurements from the airborne Raman ozone temperature and aerosol lidar during SOLVE, J. Geophys. Res., 107, doi:10.1029/2001JD001028, 2002.
Danilin, M. Y., Ko, M. K. W., Bevilacqua, R. M., Lyjak, L. V., Froidevaux, L., Santee, M. L., Zawadny, J. M., Hoppel, K. W., Richard, E. C., Spackman, J. R., Weinstock, E. M., Herman, R. L., McKenney, K. A., Wennberg, P. O., Eisle, F. L., Stempfle, R. M., Scott, C. J., Elkins, J. W., and Bui, T. V.: Comparison or ER-2 aircraft and POAM III, MLS, and SAGE II satellite measutements during SOLVE using traditional correlative analysis and trajectory hunting technique, J. Geophys. Res., 108, 8315, doi:10.1029/2001JD000781, 2003.

Kyrö, E., Kivi, R., Turunen, T., Aulamo, H., Rudakov, V. V., Khattatov, V., MacKenzie, A. R., Chipperfield, M. P., Lee, A. M., Stefanutti, L., and Ravegnani, F.: Ozone measurements during the Airborne Polar Experiment: aircraft instrument validation, isentropic trends, and hemispheric fields prior to the 1997 Arctic ozone depletion, J. Geophys. Res., 105, 14 599-14611, 2000.

Lait, L. R., Schoeberl, M. R., Newman, P. A., Proffitt, M. H., Lowenstein, M., Podolske, J. R., Strahan, S. E., Chan, K. R., Gary, B., Margitan, J. J., Browell, E., McCormick, M. P., and Torres, A.: Reconstruction of $\mathrm{O}_{3}$ and $\mathrm{N}_{2} \mathrm{O}$ fields from ER-2, DC-8, and balloon observations, Geophys. Res. Lett., 17, 521524, 1990.

Lait, L.: An alternative form for potential vorticity, J. Atmos. Sci., 51, 1754-1759, 1994.

Lait, L. R., Schoeberl, M. R., Newman, P. A., McGee, T., Burris, J., Browell, E. V., Richard, E., Braathen, G. O., Bojkov, B. R., Goutail, F., von der Gathen, P., Kyrö, E., Vaughan, G., Kelder, H., Kirkwood, S., Woods, P., Dorokhov, V., Zaitcev, I., Litynska, Z., Kois, B., Benesova, A., Skrivankova, P., De Backer, H., Davies, J., Jorgensen, T., and Mikkelsen, I. S.: Ozone loss from quasi-conservative coordinate mapping during the 19992000 SOLVE/THESEO 2000 Campaigns, J. Geophys. Res., 107, doi:10.1029/2001JD000998, 2002.

Lary, D. J., Chipperfield, M. P., Pyle, J. A., Norton, W. A., and Riishojgaard, L. P.: 3-dimensional tracer initialization and general diagnostics using equivalent PV latitude-potential-temperature coordinates Quart. J. Royal Met. Soc., 121, 187-210, 1995.

Leovy C. B., Sun, C.-R., Hitchman, M. H., Remsberg, E. E., Russell III, J. M., Gordley, L. L., Gille, J. C., and Lyjak, L. V.: Transport of ozone in the middle stratosphere: evidence for wave breaking. J. Atmos. Sci., 42, 230-244, 1985.

Lucke, R. L., Korwan, D. R., Bevilacqua, R. M., Hornstein, J. S., Shettle, E. P., Chen, D. T., Daehler, M., Lumpe, J. D., Fromm, M. D., Debrestian, D., Neff, B., Squire, M., König-Langlo, G., and Davies, J.: The Polar Ozone and Aerosol Measurement (POAM) III instrument and early validation results, J. Geophys. Res., 104, 18 785-18 800, 1999.

Lumpe, J. L., Fromm, M., Hoppel, K., Bevilacqua, R. M., Randall, C. E., Browell, E. V., Grant, W. B., McGee, T., Burris, J., Twigg, L., Richard, E. C., Toon, G. C., Margitan, J. J., Sen, B., Pfeilsticker, K., Boesch, H., Fitzenberger, R., Goutail, F., and Pommereau, J.-P.: Comparison of POAM III ozone measurements with correlative aircraft and balloon data during SOLVE, J. Geophys. Res., 108, doi:10.1029/2001JD000472, 2003.

Manney, G. L., Michelsen, H. A., Bevilaqua, R. M., Gunson, M. .R., Irion, F. W., Livesy, N. J., Oberheide, J., Riese, M., Russell III, J. M., Toon, G. C., and Zawodny, J. M.: Comparison of satellite ozone observations in coincident air masses in early November 1994, J. Geophys. Res., 106, 9923-9943, 2001. 
McGee, T. J., Gross, M., Singh, U. N., Butler, J. J., and Kimvilankani, P.: An improved statospheric ozone lidar, Opt. Eng., 20, 955-958, 1995.

Morris, G. A., Gleason, J. F., Ziemke, J., and Schoeberl, M. R.: Trajectory mapping: a tool for validation of trace gas observations, J. Geophys. Res., 105, 17 875-17 894, 2000.

Pfaendtner, J., Bloom, S., Lamich, D., Seablom, M., Sienkiewicz, M., Stobie, J., and da Silva, A.: Documentation of the Goddard Earth Observing System (GEOS) Data Assimilation System Version 1, NASA Technical Memorandum 104606, Vol. 4, 1995.

Randall, C. E., Lumpe, J. D., Bevilacqua, R. M., Hoppel, L. W., Fromm, M. D., Salawitch, R. J., Swartz, W. H., Lloyd, S. A., Kyro, E., von der Gathen, P., Claude, H., Davies, J., DeBacker, H., Dier, H., Molyneux, M. J., and Sancho, J.: Reconstruction of three-dimensional ozone fields using POAM III during SOLVE, J. Geophys. Res., 107, doi:10.1029/2001JD000471, 2002.

Redaelli, G., Lait, L. R., Schoeberl, M., Newman, P. A., Visconti, G., Daltorio, A., Masci, F., Rizi, V., Froidevaux, L., Waters, J. W., and Miller, A. J.: UARS MLS $\mathrm{O}_{3}$ soundings compared with lidar measurements using the conservative coordinates reconstruction technique, Geophys. Res. Lett., 21, 1535-1538, 1994.

Rex, M., von der Gathen, P., Braathen, G. O., Harris, N. R. P., Reimer, E., Beck, A., Alfier, R., Krüger-Carstensen, R., Chipperfield, M., De Backer, H., Balis, D., O'Conner, F., Dier, H., Dorokhov, V., Fast, H., Gamma, A., Gil, M., Kyrö, E., Litynska, Z., Mikkelsen, I. S., Molyneux, M., Murphy, G., Reid, S. J., Rummukainen, M., and Zerefos, C.: Chemical ozone loss in the Arctic winter 1994/1995 as determined by the Match technique, J. Atmos. Chem., 32, 35-59, 1999.
Richter, D. A., Browell, E. V., Butler, C. F., and Higdon, N. S.: Advanced airborne UV DIAL system for stratospheric and tropospheric ozone and aerosol measurements, in: Advances in Atmospheric Remote Sensing with Lidar, edited by: Ansmann, A., Neuber, R., Rairoux, P., and Wandinger, U., 395-398, Springer Verlag, New York, 1997.

Schoeberl, M .R., Lait, L. R., Newman, P. A., Martin, R. L., Proffitt, M. H., Hartmann, D. L., Lowenstein, M., Podolske, J., Strahan, S. E., Anderson, J., Chan, K. R., and Gary, B.: Reconstruction of the constituent distribution and trends in the Antarctic polar vortex from ER-2 flight observations, J. Geophys. Res., 94, $16815-$ $16845,1989$.

Schoeberl, M. R. and Lait, L. R.: Conservative coordinate transformations for atmospheric measurements, in: The Use of EOS for Studies in Atmospheric Physics, edited by: Gille, J. C. and Visconti, G., Proc. Internat. School of Phys. "Enrico Fermi", CXV Course, 419-430, 1991.

Schoeberl, M. R., Newman, P. A., Lait, L. R., McGee, T. J., Burris, J. F., Browell, E. V., Grant, W. B., Richard, E. C., von der Gathen, P., Bevilacqua, R., Mikkelsen, I. S., and Molyneux, M. J.: An Assessment of the Ozone Loss During the 1999-2000 SOLVE/THESEO 2000 Arctic Campaign, J. Geophys. Res., 107, doi:10.1029/2001JD000412, 2002. 